\title{
EPIDEMOLOGY AND CLINICAL ASPECTS OF HUMAN RABIES IN MINAS GERAIS, BRASIL: MISDIAGNOSIS AND MISUNDERSTANDINGS ON THE PSYCHOPATHOLOGICAL DISTURBANCES
}

\author{
Jayme Neves**; António Cándido de Melo Carvalho** *,
}

Sylvio Megre Velloso****

\begin{abstract}
This paper reports 40 cases of human rabies studied at the Carlos Chagas Hospital of UFMG. State of Minas Gerais, Brazil, from 1963 through 1976. From the epidemiological point of view it is concluded that the magnitude of the problem of human rabies in underdeveloped countries remains quite unknown. Special emphasis is given to the lack of apropriate knowledge of the recommended preventive measures, and to the influence of health education and socio-economic-cultural structure of the communities. The classic clinical picture of human rabies is briefly described, particular attention being drawn to psychopathologic features of rabies encephalomyelitis. It is pointed out that in some cases the mental symptoms may predominate from the onset of the illness, adding difficulty to the diagnosis. According to the Authors, human rabies must be differentiated from several psychopathologic syndromes and also from encephalomyelitis due to other central nervous system infections. It is discussed whether the fatalistic concept of human rabies would be somehow contributing to delay a better understanding of the natural history of the disease.
\end{abstract}

\section{INTRODUCTION}

Rabies is considered a fatal virus infection of man and animals. Epidemiological concepts of rabies in the tropical and subtropical area of the Americas have not changed in the past decade. It should be pointed out that urban rabies is a major health problem in most large cities of Latin America, where the dog has the same role as it had in North America 25 years $\mathrm{ago}^{40}$

Brazil is among a few countries with world highest incidence of rabies, in which cattle epidemics occur throughout the country and the vampire but has been incriminated as a source of rabies virus, particularly in the Southern States. Dogs represent the main source of infection for man, although foxes, cats and other animals are also involved.

Until 1969, the data collected by the Ministry of Health on human rabies were fragmentary, no records of the actual numbers of fatal cases of hydrophobia in the Country being available. From 1969 on, the OPAS/ OMS, in collaboration with the "Fundação Serviços de Saúde Pública", carried out a survey to assemble sounder epidemiological information, thus affording a more appropriate idea of the characteristics of the problem. In 1970,121 human rabies fatal infections were recorded, and the Health Services of the States attended to 120,955 people with a history of suspected animal aggression. Out of these, 75,561 subjects received post-esposure prophylaxis, resulting in the administration of 864,450 doses of antirabic vaccine ${ }^{6}$. These

* Trabalho da Clínica das Doenças Infectuosas e Parasitaries da Faculdade de Medicina da Universidade Federal de Minas Gerais, Belo Horizonte, Minas Gerais, Brasil.

Esta pesquisa foi parcialmente financiada pelo Conselho Nacional de Desenvolvimento Cientifico a Tec . nológico (CNPq).

* Professor Titular da Clínica das Doencas Infectuosas e Parasitarias.

*** Professor Assistente.

*** Psiquiatra da Secretaria de Estado da Saúde.

Recebido para publicaçăo em 28. 2,78. 
figures are far from representing the reality of the problem. In the United States, for instance, where the incidence of rabies is remarkably low, and where effective dog control laws and animal vaccine programs were established for years now, 500,000 people are bitten by animals each year and about 30,000 of these receive rabies prophylaxis.

Unfortunately, the actual magnitude of the problem of human rabies in Brazil remains quite unascertained. It is plausible to assume that the incidence of the infection in man is even higher than we realize, if we consider that besides the estimated dog population, the lage reservoir of rabies among wild animals in the tropic and subtropic regions provides a variable but constant threat to man and domestic animals. On the other hand, it is still impracticable to obtain a continous surveillance and, what is worse, to have an appropriate knowledge on the preventive measures recommended. As a result, there is no effective protection for the most important populations at risk: man and dog, the latter due to its close relationship to man and its ability to carry disease to man. There is no uniform criteria of post-exposure treatment in the country. A variety of schedules is described with different numbers of doses and volumes of antirabic vaccine for similar circunstances of exposure.

Although the epidemiology of rabies is being studied for over 2,000 years, our purpose is to review briefly this aspect of rabies based on 40 cases studied at the Carlos Chagas Hospital of UFMG from 1963 through 1976. On the other hand, we intend to discuss the most striking clinical features of this infection, with an attempt to differentiate true rabies from other psychopathologic syndromes.

\section{MATERIALS AND METHODS}

Fourty suspected cases of human rabies were admitted to the Carlos Chagas Hospital of UFMG from 1963 to 1976. Most of the patients, aged 4 to 58 years, had been examined previously as out-patients because of a faulty history, in which the right diagnosis was missed due to lack of mention of an animal exposure. Some patients were admitted with a clearly defined picture of acute encephalitìs, presumably due to rabies infection. Among these, five were patients referred from psychiatric hospitals because of a psychopathologic condition which deteriorated rapidly and unexpectedly.

Histories were recorded on especially standardized case sheets and all patients were examined by the same group. All pertinent laboratory findings were charted. The preliminary diagnosis was made on epidemiological and clinical data. Out of 40 cases, 7 were admitted to the Intensive Care Unit (ICU) to ensure both sedative procedures and maintenance of vital functions ${ }^{24}$. This group of patients was specially prepared to provide condition for intravitam virus isolation and serological procedures by means of the direct immunofluorescence test (FAT), the indirect method of FAT (IFAT) of corneal impressions, saliva, and cerebrospinal fluid, besides blood antibody titration ${ }^{32}$. The confirmation of rabies diagnosis was performed through suckling mouse inoculation and histopathologic and virologic studies of all 40 autopsied patients. Classical light and electron microscopy techniques were used at autopsy (data to be published).

\section{RESULTS}

Epidemiology - Out of the 40 patients, 21 lived in the metropolitam area of Belo Horizonte, and 18 came from different counties of the hinterland of the State of Minas Ge. rais. Sex and age distribution are shown in Table $I$ and II. It is seen that males were more liable to get the infection than females. It is also seen that the highest incidence was in the 5-14 years age group with an apparent seasonal distribution in the late winter and spring. The nature of exposure varied in extension and location. In 32 out of 33 histories of exposure the wound was produced by animal bite on limbs or face. In only one patient there was reference to scratches on the eyebrow. The animal mainly involved was the dog which was responsible for 30 out 33 aggressions. Cats followed in epidemiological importance. Although none of the stray or domestic animals were examined pathologically when sacrificed, a history of unexpected or dumb behaviour was considered sufficient to classify them as rabid animals.

The incubation period ranged from 12 to 425 days (average of 53.2 days). In the majority of untreated cases, the disease developed from 30 to 60 days after exposure. The short- 
est period of latency was of 12 days and followed minimal lacerations inflicted on the eyebrow and cheek of a 14 years old boy by a stray dog. This patient received local treatment of the wound but interrupted recommended rabies prophylaxis at the fourth dose of antirabic vaccine. The onset of symptoms was delayed for 425 days in another adolescent bitten on the foot in spite of local wound treatment and completion of a full course of 14 daily doses of suckling mouse vaccine. It appears that the variability seen in the lenght of prepatent period cannot be used as an indication of the interrelationship between the site of active virus inoculation and the proximity of the wound to the brain. It is worth emphasizing that most of the patients and their familes were unaware of the rabies problem. All but one did not seek postexposure prophylaxis or did not believe in vaccine. In some instances, the local wound treatment was the only measure recommended by inexperient physicians.

Clinical Features - After a highly variable incubation period, the onset of the disease was characterized by prodromal symptoms usually not different from those referred to in the literature, such as fever, loss of appetite, irritability, progressive nervousness, anxiety, and insomnia. In only one case it was possible to detect prodromal mental symptoms about 20 days before the onset of the disease. This patient was admitted to psychiatric hospital because his thoughts became incomprehensible: "he emphasized irrelevant ideas and failed to stress relevant ones". Thought disorders gave rise to perplexity, poor concentration, vagueness of speech and manner. At the same time he showed lack of entusiasm, excessive concern with relatives and professional activities, and morbid fear of disease. Later it was pointed out that the patient complained about "thought blocking". From the psychiatric point of view the differential diagnosis between schizophrenia and affective disorders was difficult to establish. On the other hand, differentiation from hysteria was also difficult.

Occasionally patients made reference to a sensation of burning or itching or tingling in the vicinity of the wound. The main symptom, however, was related to the act of swallowing, consisting of increased salivation, excessive sweating, sense of constriction in the throat, painful spasmodic contration of the muscles of deglution and respiration. Any fluid coming in contact with the fauces was expelled with violence. Either the slightest sight or smell of a liquid or the sound produced by pouring it from a tape brought about the spasm of the throat muscles. A blowing of air on the face produced identical painful spasmodic contration (aerophobia). Distressing thirst and dehydration were of progressive intensity.

With the rapid progress of the disease, any kind of stimulus produced excitation of the

\section{TABLE I}

Agewise and sexwise distribution of fatal cases of human rabies admitted in Carlos Chagas Hospital of UFMG during the period of $1963-1976$

\begin{tabular}{crrrrrr}
$\begin{array}{c}\text { AGE GROUP } \\
\text { (YRS.) }\end{array}$ & MALE & PERCENTAGE & FEMALE & PERCENTAGE & TOTAL & PERCENTAGE \\
\hline & & & & & & \\
$0-14$ & 3 & 7,5 & - & - & 3 & 7,5 \\
$5-14$ & 15 & 37,5 & 6 & 15,0 & 21 & 52,5 \\
$15-24$ & 4 & 10,0 & 1 & 2,5 & 5 & 12,5 \\
$25-34$ & 3 & 7,5 & 1 & 2,5 & 4 & 10,0 \\
$35+$ & 5 & 12,5 & 2 & 5,0 & 7 & 17,5 \\
\hline Total & 30 & 75,0 & 10 & 25,0 & 40 & 100 \\
\hline
\end{tabular}


TABLE ॥

Cases of human rabies identified in Carlos Chagas Hospital of UFMG from 1963 to 1976.

Summary of epidemiological and laboratory data.

\begin{tabular}{|c|c|c|c|c|c|c|c|c|c|}
\hline \multirow{3}{*}{ Name } & \multirow{3}{*}{$\begin{array}{l}\text { Age } \\
\text { yr. }\end{array}$} & \multirow{3}{*}{ Sex } & \multirow{3}{*}{ Nature of exposure } & \multirow{3}{*}{$\mid \begin{array}{c}\text { Incubation } \\
\text { period } \\
\text { (days) }\end{array}$} & \multirow{3}{*}{$\begin{array}{l}\text { Length } \\
\text { of } \\
\text { illness } \\
\text { (days) }\end{array}$} & \multirow{3}{*}{$\begin{array}{l}\text { Postexposure } \\
\text { profilaxis }\end{array}$} & \multicolumn{3}{|c|}{ Diagnosis } \\
\hline & & & & & & & \multirow[t]{2}{*}{ in vivo } & \multicolumn{2}{|c|}{ Postmortem } \\
\hline & & & & & & & & $\begin{array}{l}\text { Histopa- } \\
\text { tology } \\
\text { (Negri } \\
\text { bodies) }\end{array}$ & $\left\{\begin{array}{c}\text { Inocul. } \\
\text { (suckling } \\
\text { mice) }\end{array}\right.$ \\
\hline WAS & 9 & $\mathbf{M}$ & Bite on hand by a rabid dog. & 30 & 10 & None & - & + & + \\
\hline PR & 9 & $\mathbf{M}$ & Bite on foot by a rabid dog. & 60 & 6 & None & - & + & + \\
\hline MFP & 5 & $\mathbf{F}$ & Bite on fore arm by a stray dog & 18 & 3 & None & - & + & + \\
\hline $\mathrm{ACS}$ & 39 & $\mathbf{F}$ & Bite on finger by a rabid dog. & 60 & 10 & $\begin{array}{l}\text { Wound washed } \\
\text { with soap }\end{array}$ & - & + & + \\
\hline LLF & 27 & $\mathbf{M}$ & Unknown & $?$ & 4 & $?$ & - & + & + \\
\hline AEB & 10 & $\mathbf{M}$ & $\begin{array}{l}\text { Scratch on eyebrow by } \\
\text { domestic dog. }\end{array}$ & 30 & 3 & None & - & + & + \\
\hline$?$ & $30 ?$ & $\mathbf{M}$ & Unknown & $?$ & 3 & $?$ & - & + & + \\
\hline RMA & 4 & $\mathbf{M}$ & Unknown & $?$ & 12 & $?$ & - & + & + \\
\hline FFS & 45 & $\mathbf{M}$ & $\begin{array}{l}\text { Bite on hand by a stray and } \\
\text { rabid cat. }\end{array}$ & 60 & 14 & $\begin{array}{l}\text { Local treatment } \\
\text { with water and } \\
\text { antiseptics. }\end{array}$ & & & \\
\hline DO & 23 & $\mathbf{M}$ & Bite on hand by a stray dog. & 30 & 4 & None & - & + & + \\
\hline MFP & 8 & $\mathbf{M}$ & Bite on leg by a stray dog. & 40 & 3 & None & - & + & + \\
\hline FFS & 12 & $\mathbf{M}$ & Bite on forearm by a stray dog. & 60 & 9 & None & - & + & + \\
\hline MLS & 22 & $\mathbf{F}$ & Bite on leg by a stray dog. & 60 & 7 & None & - & + & + \\
\hline MFA & 58 & $F$ & Bite on hand by a rabid dog. & 60 & 3 & None & - & + & + \\
\hline CGS & 12 & $\mathbf{M}$ & Bite on hand by a stray dog. & 90 & 5 & None & - & + & + \\
\hline OSC & 22 & $\mathbf{M}$ & Bite on finger by a stray dog. & 21 & 3 & $\begin{array}{l}\text { Local treatment } \\
\text { with antiseptics }\end{array}$ & - & + & + \\
\hline $\mathrm{CHC}$ & 4 & $\mathbf{M}$ & Bite on hand by a domestic dog. & 35 & 4 & $\begin{array}{l}\text { Local treatment } \\
\text { with antiseptics }\end{array}$ & - & + & + \\
\hline MCS & 22 & $\mathbf{F}$ & Unknown & $?$ & 4 & None & - & + & + \\
\hline MS & 12 & $\mathbf{F}$ & Unknown & $?$ & 3 & None & - & + & + \\
\hline MGS & 13 & $F$ & Bite on hand by a stray dog & 41 & 8 & None & - & + & + \\
\hline FAP & 5 & $\mathbf{M}$ & Bite on eyebrow by a stray dog. & 30 & 4 & $\begin{array}{l}\text { Local treatment } \\
\text { with antiseptics }\end{array}$ & - & + & + \\
\hline MGO & 4 & $\mathbf{M}$ & Unknown & $?$ & 8 & None & - & + & + \\
\hline JMO & 12 & $\mathbf{M}$ & Unknown & $?$ & 5 & None & - & + & + \\
\hline JAM & 14 & $\mathbf{M}$ & Bite on hand by a stray dog. & 60 & 4 & None & - & + & + \\
\hline JAS & 10 & $\mathbf{M}$ & Bite on leg by a domestic cat. & 150 & 7 & $\begin{array}{l}\text { Local treatment } \\
\text { with antiseptics }\end{array}$ & - & + & + \\
\hline LF & 8 & $\mathrm{~F}$ & Bite on leg by a stray dog. & $?$ & 4 & None & & + & + \\
\hline IS & 24 & $\mathbf{M}$ & Bite on hand by a domestic cat. & 72 & $21^{*}$ & $\begin{array}{l}\text { Local treatment } \\
\text { with antiseptics }\end{array}$ & - & + & + \\
\hline ALF & 14 & $M$ & Bite on foot by a stray dog. & 425 & $26^{*}$ & $\begin{array}{l}\text { Local treatment } \\
\text { and } 14 \text { doses of } \\
\text { suckling mice } \\
\text { vacine }\end{array}$ & + & + & + \\
\hline JDS & 8 & $F$ & Bite on leg by a domestic dog. & 81 & $15^{*}$ & $\begin{array}{l}\text { Local treatment } \\
\text { with antiseptics }\end{array}$ & + & + & + \\
\hline MGF & 42 & $\mathbf{M}$ & Bite on hand by a stray dog. & 90 & $28^{*}$ & None & + & + & + \\
\hline RPG & 14 & $\mathbf{M}$ & $\begin{array}{l}\text { Bite on eyebrow and cheek } \\
\text { by a stray dog. }\end{array}$ & 12 & $12^{*}$ & $\begin{array}{l}\text { Local treatment } \\
\text { and doses of } \\
\text { suckling mice } \\
\text { vacine }\end{array}$ & + & + & + \\
\hline GR & 11 & $\mathbf{M}$ & Bite on leg by a stray dog & 90 & $11^{*}$ & $\begin{array}{l}\text { Local treatment } \\
\text { with antiseptics }\end{array}$ & + & + & + \\
\hline WLC & 40 & M & Bite on nose by a domestic dog. & 62 & $18^{*}$ & None & + & + & + \\
\hline
\end{tabular}

* Patients admitted to the Intensive Care Unit (ICU) 
muscular system, and apnoea and cyanosis resulted from excessive spasm of the respiratory muscles. Psychomotor activity was invariably increased inducing contractures and convulsive seizures of difficult therapeutic control. In the majority of the patients death took place during the convulsion phase, 3-5 days after admission. Death was delayed in some cases, particularly in those submitted to interisive care ${ }^{24}$. In such circumstances, death occurred after progressive apathy, paralysis and coma.

The clinical picture briefly described corresponds to the spastic form of rebies which offers little difficulty in diagnosis. In some cases, however, mental symptoms may predominate from the onset, and the psychopathological form of the disease may remain undiag nosed. The following are fairly typical examples of mental features of rabies encephalitis:

One patient (not identified) was admitted with mental disturbances characterized by a syndrome of furious agitation. He was brought to the hospital by a patrol of six police officers. Just before admission, this man, apparently aged 30, had an outbreak on the street in which he begun to show signs of excitability of the sexual function and committed several acts of gross indecency. After a battle in which the patient defied any one to come near him, the policemen were able to subdue him and brought him immediately to the hospital. There were no other elements to the history. Physical findings displayed evidence of severe mental disorder, but the following symptoms deserved particular attentio: fever, inability to control the bodily functions, profuse salivation, intense thirst, difficulty in swallowing, dread of water, and aerophobia. Sedation represented a difficult problem, and death occured 3 days after admission. Confirmation of rabies diagnosis was performed through suckling mouse inoculation and histopathologic and virological studies of autopsy material.

$M F A$, a female aged 58, also showed an acute syndrome of furious agitation. She had been admitted six days earlier with a clearly defined picture of acute encephalitis attributed to rabies of the spastic form. The unusual lenght of the disease warranted a diagnosis revision, but a few hours after interruption of sedative measures she had an outbreak in which she began to break windows with a chair, kicked her husband down the bed, struck him, nurses and residents with a chair. pickec up a table throwing it against the wall, and fought with anyone who happened to be near her. She was extremely violent, abusive and obscene. From time to time she sat up with her eyes staring wide with helpless terror. Neither sedatives (chlopromazine, diazepam, promethazine), nor anticonvulsivants (diphenylhydantoin, phenobarbital), quited her and death occurred six days later. Rabies diagnosis was confirmed at autopsy.

In three other patients there were grand mal epileptic attacks. A man aged 24 , about four days after exhibiting prodromal symptoms of rabies, became extremely irritable, resistive and suspicious. Unexpectedly he travelled from village to village in an apparent epileptic fugue state. Three days later he was found with complete disorientation for time, place and person. The family history was not helpful, but the personal history disclosed a description of a bite on the hand, by a domestic cat. At the examination the mood at this stage was euphoric, talkative and restless. During examination he had generalized convulsive seizures. He was admitted to the $\mathrm{ICU}$ and died 21 days later. The diagnosis of rabies was performed with the patient still alive through virus isolation from saliva ${ }^{32}$.

$M L S$, a girl aged 12 , although more talkative than the usual, seemed to be perfectly orientated for time, place and person. Further questioning revealed the patient quite expan. sive and intelligent, while the predominant mood was one of hypereuphoria. At times she became transitorily irritable and impatient. Speech was coherent, relevant and clear. When invited to drink water or stimulated by blowing on her face, she began to speak disconnectedly and then cursed, laughed and became increasingly excited. She screamed abuse in filthy language, and struck out aimlessly with arms and legs. Her mother was bitterly disappointed, telling us that she had always been a "good" girl. Sometimes the patient whispered and apparently talked to strange voices, mouthing obscenities and moaning meaningless words over and over. Five days later rabies diagnosis was confirmed at autopsy.

Patients may develop suggestive symptoms of a schizophrenic or affective psychosis. Hallucinations and delusions were not infrequent, the former being predominantly seen in children. Visual hallucinations were often very elementary and ill-defined, such as kaleidoscopic or ghost-like figures and forms. 
Hallucinations affecting other senses were less frequent. The mental symptoms began sometimes before the onset of the characteristic clinical picture of rabies in the prepatent period.

On one ocasion only it was possible to identify a typical picture of the paralytic form of rabies, i.e., a clinical picture in which the paralytic symptoms predominated from the onset of the disease. When admitted to Carlos Chagas Hospital, a flaccid type of paralysis had gradually ascended in both legs of a 9 years-old white boy, that received only local treatment of the wound.

The differentiation of some rabic mental disturbances from hysteria was very difficult, because hysteria can mimic any illness, including various forms of psychosis. For instance, the family of MCS, a 22-years-old woman, insisted on the point that all the symptoms atributed to rabies, including psychomotor activity, hydrophobia and aerophobia, were constantly precipitated whenever she got into a difficult situation. Thus, her extremities would fall but never hurt herself, and occasionally she would present difficulty in swallowing and vomited. In her husband's view, she was only suffering from what a physician would recognize as a hysterical reaction. Four days later she was dead and the diagnosis of rabies was confirmed at autopsy.

As a matter of fact, the greatest difficulty in separating the characteristic clinical picture of rabies and hysteria lies in the distressing concept that rabies is invariably a fatal infection of man. On other words, diagnosis of rabies has usually been precluded when the patient is able to survive from an unexpected, acute, and almost always dramatic neurologic and/or mental syndrome of unknown origin. Thus, it seems quite clear that "rabies hysteria" may be perhaps the only justification for the foolhardy definition of a "difficult diagnosis". There may be something a little shocking about this idea, however, the next case illustrates how embarrassing this dogmatic statement would appear to physician in endemic areas of rabies.

$A A S$, a 11 years-old boy, was bitten on the left lower extremity by a stray dog, without receiving local or other treatment. Seventy-five days later an unexpected change in the behaviour and mood of the child took place. He became quarrelsome, irritable and pestered those around him to allow him up and down. Within a few days he began to have outbreacks during which he shrieked hysterically, mouthed obscenities, cursed for nothing and beated anyone who tried to restrain him. On occasion there were cenesthesic and visual hallucination with persecutory features. It was necessary to place him in reclusion. Violent fits of rage and terror followed, and he was admitted to a psychiatric institution where sedatives and hypnotics were prescribed. After a short period of observation he was referred to Belo Horizonte, where a preliminary diagnosis of rabies was made; patient was admitted to the ICU for aggressive supportive care.

There was no personal or familiar history of mental disturbances. The patient was normally developed and nourished, and at the psychiatric interview he showed some degree of recentment toward his mother (who left home after his father's death) and hostility toward his uncles (with whom he lived). Ori admission he seemed appathetic, but cooperative and well-oriented. He looked scared, with increased. sensitivity to draughts, bright light stimuli and loud and sudden noises. A discrete difficulty in swallowing and a painful constriction in the throat were observed. When forced to drink, fluids were regurgitated without visible effort, but on other occasions fluid was taken readily and without apparent constraint. There was no aerophobia. A discrete motor inccordination of the lower extremities was noted, with neurologic examination otherwise normal.

Serological studies for rabies were negati$\mathrm{ve}^{32}$ The patient was discharged from ICU and admitted to the Carlos Chagas Hospital, where he was placed on diazepam. He soon became cheerfull, friendly and no longer agitated. Despite this improvement, the motor incoordination of his lower extremities was the cause of several falls, and the factor responsible for complete fracture of both arms. His condition improved remarkably and he was finally discharged $\mathbf{3 5}$ days after the onset of his illness, with a remainder motor incoordination. His final diagnosis was "abnormal living reaction of the hysterical type".

\section{DISCUSSION}

Rabies infection in the brain develops rapidly and affects all its parts with devastating severity. A prompt diagnosis is warranted 
When the mental symptoms, including changes in character, impairment of intellectual capa. city, hallucination, paranoid features, psychomotor disturbances and others, make up a recognizable syndrome. However, if patient is seen in the early stages of the infection, other organic conditions such as epilepsy, brain trauma, alcoholism, syphilis, arteriosclerosis, postencephalitic syndrome and brain tumor, and the functional condition of hysteria can be mimicked, rendering the differential diagnosis difficult. As shown by some of our described cases, misdiagnosis are sometimes performed either by physicians or psychiatrists.

Paralytic symptoms alone may occur in 15 to 60 per cent of the cases ${ }^{21}, 26$, varying in localization and in evolution. This fact emphasizes the need for a more searching enquiry by physicians regarding possible attack by rabid animals, particularly by vampire bats, although the history of an aggression is always difficult to obtain. On the other hand, paralytical forms may follow a more protracted course than furious rabies, survival ranging in the formers from one week to 133 days $^{9}, 35$. In the case well described by Hattwick et $\mathrm{al}^{15}$, the recovery from clinical encephalomyelitis was complete six month after the onset.

Strinking mental symptoms may be either present or absent in human rabies, and their mode of appearance probably depends upon the patient's previous personality pattern. Furthermore, it may be rather difficult to yield a previous exposure to attacks by rabid animals on the basis of history alone. In consequence it is wise to think on rabies when a patient with unexpected change in behaviour and mood comes from an endemic region, exhibits an acute evolution and presents noncharacteristic psychopathological features.

Our main purpose is to point out some circumstances under which rabies diagnosis, though not easy to be ruled out, has to be differentiated from those cases described in the literature as "rabies hysteria", "psychological rabies", or from encephalomyelitis due to other viruses, particularly when evidence of exposure to rabid animals is lacking or doubtiful. The above described case of patient $A A S$ illustrates this problem. The final diagnosis in that case, even considering the lack of more detailed information from the family about the child's personality make-up and the relative severity of the motor incoordination of his lower extremities, was an "abnormal living reaction of the hysterical type". This inference, of course, discloses embarrassing ambiguities. On the other hand, how troublesome it would appear to compare this "typical epidemiological and clinical picture of rabies" with the one recorded by Hattwick et al. ${ }^{15}$, that was considered "the first well-documented human case of rabies recovery". In both circumstances, however, it would be wiser to rear on Koch's doctrines, stating that it is unfortunate for strict scientific recording that the aetiological agent could not be isolated from the patients. As pointed out by Vella ${ }^{44}$, when discussing the case reported by Hattwick and his colleagues, the serological results obtained in both cases have to be regarded as only second-best evidence in diagnostic work.

Rabies in human beings is generally regarded as being invariably fatal. The basic causes for this hopeless prognosis are beyond our present knowledge. Some evidence has been gathered, however, based on which this ancient fatalistic concept seems to be denied and the possibility of recovery from rabies may become conceivable. Among the arguments which sustain this possibility, the following may be emphasized:

(a) several reports of non-fatal or abortive rabies in different animals species are avaiable in the literature $1,2,4,5,8,13,14,23,29,31,36$, 39,46,47;

(b) experimental studies have shown that a high percentage of animal are able to recover from well-defined clinical rabies $3,7,11$, $12,20,45$.

(c) fatal human rabies occurs in individuals bitten by apparently healthy animals $9,30,34$, 41,4247 .

(d) there are evidences of the existence of possible differences in antigenicity, infectivity and pathogenicity among strains of rabies virus, which provides the probable explanation to the rarity of human cases in regions where rabies is highly enzootic ${ }^{19,22}$, the low pathogenicity of strains isolated from wild animals ${ }^{17,18,26,37,43}$, and the protracted course of some cases of the disease in animals ${ }^{17}$ and in humans ${ }^{16,35}$;

(e) finally, there are a few reports on alledged cases of human recovery from rabies, the majority of them not clearly documented ${ }^{15}$, $25,27,28,33$, and one report on a case considered the first well-documented case of human recovery ${ }^{15}$, although even is this latter the aetiological agent could not be isolated from the patient. 
To call into question what everybody regards as obvious may provoke anything from amused tolerance to open hostility. We do believe, however, that to do so may not always be mere sophistry: it is perhaps not illogical, then to admit that rabies is a disease from which recovery is theoretically possible. Otherwise, it seems pertinent to inquire into the causes of such a theoretical assumption that rabies is invariably fatal only in man. Moreover, the belief that human rabies runs fatalistically towards death may be contributing anyway to delay a better understanding of the natural history of the disease, thus perpetuating the circumstances favouring the misdiagnosis which are our main subject in this paper. The point is that "psychological rabies", "rabies hysteria" or "abnormal living reactions", may sometimes well represent a label with which we are trying to disguise the gaps in our knowledge on the natural history of the illness.

Should we only be overemphasizing the knowledge about the most severe forms of rabies? What could make a rabid patient survive? What would be the importance of possible chronic sequelae as a cause of residual deterioration of intellect and personality? As a matter of fact we are not able to contribute to the answers for these puzzling questions. We do believe, however, that much more work is needed on this difficult problem, particularly because it do not appear to be problem at all.

Aknowledgements. - This work was partly supported by the "Conselho Nacional de Desenvolvimento Científico e Tecnológico (CNPq).

Thanks are due to Dr. M. López, Dr. W. L. Tafuri, Dr. R. Reis and Dr. G. B. Campos and to the other members of the medical staff of human rabies for their help at many points in this study.

\section{RESUMO}

No trabalho são estudados 40 casos de raiva humana identificados no Hospital Carlos Chagas da UFMG, Minas Gerais, Brasil, durante o período compreendido entre $1963 e$ 1976. Do ponto de vista epidemiológico, concluiu-se que a magnitude do problema gerado pela raiva nos países em desenvolvimento permanece ainda desconhecida. Neste particular, merecem realce o inadequado conhecimento das medidas preventivas recomendadas $e$ a influência de fatores dependentes da educação sanitária e das estruturas sócio-econômica e cultural das comunidades. Descreveu-se sumariamente o quadro clínico clássico da encefalomielite rábica, ressaltando-se suas peculiaridades psicopatológicas. Salientou-se que, em alguns casos, a sintomatologia mental pode predominar desde o início da doença, acarretando dificuldades ao diagnóstico. Segundo os Autores, a raiva humana deve ser diferenciada de diversas síndromes psicopatológicas, bem como de encefalomielites devidas a outras infecções do sistema nervoso central. Finalmente, questiona-se, baseado na casuística apresentada, se o conceito fatalístico da raiva humana não estará contribuindo de algum modo para retardar um melhor conhecimento da história natural da doença.

\section{REFERENCES}

1. ANDRAL, L. \& SÉRIÉ, C.: Études expérimentales sur la rage en Ethiopie. Ann. Inst. Pasteur (Paris) 93: 475. 488, 1957.

2. ANDRAL, L. \& SERIE, C.: Études experimentales sur la rage en Ethiopie. IV. Inféccion rabique latente. Porteur assyntomatique ou porteur silencieuse. Ann. Inst. Pasteur (Paris) 108: 442-451, 1965.

3. BELL, J. F.: Abortive rabies infection. I. Experimental production in white mice and general discussion. J. Inf. Dis. 114: 249-257, 1964.

4. BELL, J. F.: Abortive rabies. International Symposium on rabies. Intern. Ass. of Microbiology Societies. Talloires. Lac D'annecy France, 1965.

5. BELL, J. F.: Chronic rabies infection. Proc. Nat. Rabies Symposium, NCDC, Atlanta, Georgia, USA pp 17. 21, 1966.

6. Boletim Epidemiológico - Ministério da Saúde - Situação da Raiva no Brasil. Nos 5-6, 1972.

7. BOLIN, V.S.: Survival of a guinas pig following infection with street ravies virus: a case report. J. Am. Vet. Med. Assoc. 134: 90-92, 1959. 
8. BROZ, O. \& PHAN TRINH: Contribution au problème du chien "porteur sain" de virus rabique. J. Hyg. Epid. (Praha) $6: 73-78,1961$.

9. Center for Disease Control - Human rabies - California. Morbid Mortal Weekly Rep. 20: 135-142, 1971.

10. CAVEAU (in Remlinger, 1907).

.11. DAUNOY, R.: Spontaneous recovery of rabbit from experimental rabies. $J$. Inf. Dis. 34: 425-427, 1924.

12. D'SILVA, C. B.: Studies on rabies. VIII. Observations on recovery from rabies, prolonged illness in rabies and neurosterilization. Indian J. Med. Res. (Calcutá) 40: 317-325, 1952.

13. FORST, J.: Beitrag zur kenntnis atupischer und abortiver Lyssaformer bei Hunden. Klin. Spisv. Vys. Sk. Zverolek, Brunn. Tchecols. 1: 10-1924 (in Trop. Dis. Bull. 21: 708-714, 1924).

14. HALASZ, E.: Un cas de rage guerie chez un bovin (in Réc. Méd. Vet. 111: 286,1935 ).

15. HATTWICK, M. A. W.; WEIS, T. T.; STECHSCHULTE, J.; BAER, G. M., GREG, M. B.: Recovery from rabies. A case report. Ann. Int. Med. 76: 961-942, 1972.

16. HELD, J. R.; TIERKEL, E. S. \& STEELE, J. H.: Rabies in man and animals in the United States, 19461965. Public Health Rep. 82: 10091018, 1967.

17. JOHNSON, H. N.: Rabies. in Viral and Rickettsial Infections of Man. Revers, T. J. B., Lippincott co., Philadelphia, 1959.

18. JOHNSON, H. N.: Sporadic cases of rabies in wildlife: relation to rabies in domestic animals and character of virus. Proc. Nat. Rabies Symposium, NCDC, Atlanta, Georgia, USA, pp 25-30, 1966.

19. KANTOROVICH, R. A.; DONOVALOV, G. V.; BUZINOV, I. A. \& RIUTOVA, V. P.: Experimental investigations into rage and rabies in polar foxes. Study of rage in polar foxes. Acta Virol. (Praha) 7: 554-560, 1963.

20. KITSELMAN, C. G.: Recovery of a rat from experimentally induced rabies. J. Am. Vet. Med. Assoc. 144: 1113 . $1114,1964$.
21. KRAUS, R.; GERLACH, F. \& SCHWEINBURG, F.: Lyssa bei Mensch und Tier. Berlin, Urban und Schwarzenberg, pp 148-166, 1926.

22. KUBES, V. \& GALLIS, F.: La cerebroneutralización, nueva reacción biologica para el virus rabico. Su relación com la prueba de protección y la sero-neutralización. Bol. Inst. Invest. Vet. 1: 103-150, 1943.

23. LIEOU, Y. C.: Carriers of rabies virus. Chin. Med. J. 66:694-699, 1948.

24. LOPEZ, M.; NEVES, J.; MOREIRA, E.C.; REIS, R.; TAFURI, W. L.; PITTELA R. E.; MARINHO, R. P.; MARRA, U. D.; ALVARES, J. M.; DINIZ, I.; SILVA, O. S.; FOSCARINI, L. F.; CAMPOS, G. B.; MARTINS, M. T.; TOFANI, M. T.: Human rabies. I. Intensive treatment. Rev. Inst. Med. trop. São Paulo 17: 103-110, 1975.

25. MARTIN, L. A.: Infection rabique et rage curable. Maroc. Med. (Casablanca) 42: 467-473, 1963.

26. NEVES, J.: Raiva humana: Estudo clínico e atualização da profilaxia. Rev. Assoc. Méd. Minas Gerais 21: 13-22, 1970.

27. NILSSON, M. R.: Revisão do conceito de que a raiva é sempre fatal. Bol. Ofic. Sanit. Panamericana 68: 486-494, 1970.

28. OFFEMBERG, W.: Cas de rage guéri chez I'home. Rec. Med. Vet. 61:559-566, 1884.

29. PAWAN, J. L.: The transmission of paralytic rabies in Trinidad by the vampire bat. Ann. Trop. Med. Parasit. 30: 101-130, 1936.

30. PÉREZ-GONZALEZ: In Martin, L. A., Infection rabique et rage curable. Marc. Med. (Casablanca) 42: 467, 1963.

31. PHILIPS, J. M.; BERRY, F. \& SNOOK, J. H.: Recovery of animals apparently rabid. J. Infect. Dis. 29: 96-108, 1921.

32. REIS, R.; MOREIRA, E. C.; NEVES, J.; LOPEZ, M.; TAFURI, W. L.; PITTELA, J. E.; MARINHO, R. P.; MARRA, U. D.; ALVARES, J. M.; DINIZ, I.; SILVA, O. R.; FOSCARINI, L.G.; MARTINS, M. T. \& TOFANI, M. G.: Human rabies. II. Serological studies and intravitam virus isolation. Rev. Inst. Med. trop. São Paulo 18: 393401, 1976. 
33. RELOVA, R. N.: Hydrophobia: its prevention and cure. S. Tomáz J. Med. 11:259-270, 1956.

34. REMLINGER, P.: La guérison spontanée de la rage experimentale du chien et la persistance du virus rabique dans la salive des animaus guéris. Réc. Méd. Vét. 84: 269-280, 1907.

35. RUBIN, R. H.; SULLIVAN, L. \& SUMMERS, R.: A case of human rabies in Kansas: epidemiologic, clinical, and laboratorial consideration. J. Infect. Dis. 122: 318-322. 1970.

36. SChOENING, H. W.: Rabies. Proc. Sixth Pacific Science Congress (San Francisco, University of California) 5: 191-196, 1969.

37. SCHNEIDER' L. G. \& SCHOOP, U.: Pathogenesis of rabies and rabies-like viruses. Ann. Inst. Pasteur (Paris) 123: 469-476, 1972.

38. SIKES, R. K.: Guidelines for the control of rabies. Am. J. Pub. Hith. 60: 1133-1138, 1970.

39. STARR, L.; SELLERS, T. E. \& SUNKES, E. J.: Apparent recovery of a dog from rabies. JAMA 121:296, 1973.

40. STEELE, J. H.: The epidemiology and control of rabies. Scand. J. Infect. Dis. 5: 299-312, 1973.

41. THIÉRY, J.: Un chien d'apparence saine peut-il transmettre la rage? Rev. Gen. Med. Vet. 58: 451-460, 1929.

42. VEERARAGHAVAN, N.; GAJANANA, A. \& RANGASAMI, R.: Hydrophobia among persons bitten by apparently healthy animals. The Pasteur Institute of Southern India. Coonoor, Sci. Rep. 19: 90-91, 1967.

43. VEERARAGHAVAN, N.: Hydrophobia among persons bitten by apparently Healthy animals. The Pasteur Institute of Southern India. Coonoor Sci. Rep. 19: 71, 1968.

44. VELLA, E. C.: Correspondence. Lancet 5:277, 1972.

45. WEBSTER, L. T.: A mouse test for measuring the immunizing potency of antirabies vaccines. J. Exp. Med. 70 : 87-106, 1939.

46. WEBSTER, L. T.: Rabies. McMillan Co., New York, 1942.

47. YOURKOVSKY, A. M.: Hydrophobia following the bite of apparently heal. thy dogs. J. Hyg. Epidm. (Praha) 6: 73-78, 1962. 